\title{
Renal function in $\beta$-thalassemia major receiving desferal versus deferasirox
}

\author{
Foroogh Sabzghabaei ${ }^{1}$, Maryam Darnahal ${ }^{1^{*}}$, Azita Azarkeivan ${ }^{2}$ \\ ${ }^{1}$ Department of Internal Medicine, Iran University of Medical Science, Tehran, Iran \\ ${ }^{2}$ Department of Thalassemia Clinic, Transfusion Research Center, Institute for Research and Education in Transfusion Medicine, Tehran, Iran
}

\section{A R T I C L E I N F O}

Article Type:

Original

\section{Article History:}

Received: 9 May 2017

Accepted: 1 September 2017

Published online: 6 September 2017

\section{Keywords:}

Desferal

Deferasirox

Hypercalciuria

$\beta$-Thalassemia

Proteinuria

Glomerular filtration rate

\begin{abstract}
A B S T R A C T
Introduction: Deferasirox is a new oral iron chelating agent which has been administered in $\beta$-thalassemia major patients in last few years. There is some reports regarding nephrotoxicity of this agent; however, no comparative study has been conducted yet.

Objectives: The aim of this study was to compare the prevalence of kidney dysfunction in $\beta$-thalassemia major patients receiving either desferal or deferasirox as iron chelating agents. Patients and Methods: In this cross-sectional study, adult patients with $\beta$-thalassemia major who received $25 \mathrm{mg} / \mathrm{kg} / \mathrm{d}$ of desferal or $25 \mathrm{mg} / \mathrm{kg} / \mathrm{d}$ of deferasirox were studied. We compared them for serum calcium (Ca), creatinine (Cr) levels and 24 hours urine collection for proportion of $\mathrm{Ca}$ and protein. Estimated glomerular filtration rate (eGFR) was calculated by Cockcroft-Gault formula.

Results: Twenty-seven patients receiving desferal and 23 patients receiving deferasirox were evaluated. There was no significant difference of calciuria $(P=0.19)$, glycosuria $(P=0.508)$, mean 24-hour urine proteinuria $(P=0.44)$, mean serum $\mathrm{Cr}(P=0.47)$, serum Ca level $(P=$ $0.067)$ and mean eGFR $(P=0.42)$ between two groups.

Conclusion: There is no significant difference of hypercalciuria, glycosuria, mean eGFR, proteinuria, and also serum $\mathrm{Cr}$ between $\beta$-thalassemia major patients who received desferal or deferasirox.
\end{abstract}

Implication for health policy/practice/research/medical education:

In a study on $50 \beta$-thalassemia major patients (27 individuals receiving desferal and 23 with deferasirox) no significant difference of renal function, hypercalciuria, glycosuria and proteinuria between two groups was detected.

Please cite this paper as: Sabzghabaei F, Darnahal M, Azarkeivan A. Renal function in $\beta$-thalassemia major receiving desferal versus deferasirox. J Renal Inj Prev. 2018;7(3):148-151. doi: 10.15171/jrip.2018.37.

\section{Introduction}

Thalassemia is a form of inherited hematologic disorder of hemoglobin synthesis due to $\alpha / \beta$-globin chain imbalance. It leads to ineffective hematopoiesis. The most severe form is $\beta$-thalassemia major which requires long-term transfusion to correct anemia. Since there is no physiologic active mechanism for the excretion of iron, regular transfusions cause iron overload (1). Excess iron accumulates in heart, spleen, liver and leads to overproduction of free radicals; which causes organ damages (2-4).

Since, the main reason of death in patients with $\beta$-thalassemia major is heart failure due to myocardial iron deposition, iron chelating agents have increased the life expectancy of patients (5-7).
Regular administration of deferoxamine as a chelating agent first introduced in 1960, nearly doubled lifetime of patients (8-10). Deferoxamine needs slow subcutaneous infusion over 8-12 hours with high lifetime costs (9-11). In the recent two decades, introduction of two oral chelating agents; deferiprone and deferasirox, much preferred by patients. These two drugs have improved treatment of $\beta$-thalassemia major patients significantly (10).

The prevalence of hypercalciuria and renal stones is higher in patients with $\beta$-thalassemia major $(12,13)$. Studies have shown that prevalence of renal stone is higher in patients using deferasirox or deferiprone with unknown reason $(14,15)$.

Higher urinary excretion of calcium $(\mathrm{Ca})$ increases the 
risk of $\mathrm{Ca}$ phosphate and $\mathrm{Ca}$ oxalate stone formation. The risk of stones increases with increased urinary $\mathrm{Ca}$ excretion $>100 \mathrm{mg} / \mathrm{d}$. However, there is no unique cut off and definition for hypercalciuria $(16,17)$.

There are limited data considering the effect of thalassemia on kidney. Recent data suggests that deferasirox may be nephrotoxic, since high doses intravenous injections of deferoxamine could have adverse renal effects (18).

Since, there are not enough studies on side effects of chelation therapy in patients with $\beta$-thalassemia major, we compared the prevalence of renal dysfunction in patients with $\beta$-thalassemia major receiving desferal (deferoxamine) compared to deferasirox.

\section{Objectives}

The aim of this study was to compare the renal effects of desferal versus deferasirox in $\beta$-thalassemia major patients.

\section{Patients and Methods}

Twenty-seven patients injecting $25 \mathrm{mg} / \mathrm{kg} / \mathrm{d}$ of desferal and 23 patents receiving $25 \mathrm{mg} / \mathrm{kg} / \mathrm{d}$ of deferasirox orally, who also took 1-3 Ca carbonate tablets per day as supplement, were selected based on systematic random sampling method. Serum $\mathrm{Ca}$ and creatinine $(\mathrm{Cr})$ were checked and 24 hours urine was collected to analyze proportion of protein and Ca. Random urine analysis was done and glycosuria was checked by dipstick.

\section{Ethical issues}

The research followed the tenets of the Declaration of Helsinki. Informed consent was obtained. The study protocol was approved by the Ethics Committee of Iran University of Medical Science (\#93-02-30-24649).

\section{Statistical analysis}

Analysis was performed in SPSS version 22 software (IBM; Chicago, IL, USA). We used mean and standard deviation (SD) or median and interquartile range (IQR) to describe numerical variables and relative frequency percentage to describe the nominal or categorical variables. Chi-square test was applied to compare qualitative outcomes between two groups and independent $t$ test to compare quantitative outcomes between two groups. The level of significance was 0.05 for two-sided tests.

\section{Results}

Twenty-seven patients receiving daily desferal injection and 23 patients receiving daily oral deferasirox were evaluated. In desferal group 55.5\% were male and in deferasirox group $52.17 \%$ were male.

Patients in desferal group received $850 \mathrm{mg}$ Ca averagely, and patients in deferasirox group received $800 \mathrm{mg}$ averagely which was not significantly different between the groups $(P=0.78)$.

Overall $70 \%$ of patients had hypercalciuria by definition of 24 hours urine $\mathrm{Ca}>100 \mathrm{mg}$. The proportion of 24 hours urine Ca of more than $100 \mathrm{mg} / \mathrm{d}$ is significantly higher in female group who received desferal (Table 1).

Additionally, the proportion of glycosuria was different among two groups. In desferal group, only $7.4 \%$ had glycosuria while, in deferasirox group 13\% had glycosuria, however, it is not significant $(P=0.508)$.

The estimated glomerular filtration rate (eGFR) in desferal group and deferasirox group were $120.45 \pm 35.25$ $\mathrm{mL} / \mathrm{min} / 1.73 \mathrm{~m}^{2}$ and $\left.112.80 \pm 31.27\right) \mathrm{mL} / \mathrm{min} / 1.73 \mathrm{~m}^{2}$ respectively $(P=0.42)$. Accordingly 24 hours urine protein excretion in desferal and deferasirox groups were $110 \mathrm{mg} /$ day and $188.09 \mathrm{mg} / \mathrm{d}$ respectively $(P=0.44)$.

Furthermore, the mean serum $\mathrm{Cr}$ level between two groups were $0.68 \pm 0.12 \mathrm{mg} / \mathrm{dL}$ and $0.67 \pm 0.11 \mathrm{mg} / \mathrm{dL}$ respectively $(P=0.47)$. Likewise, the mean serum $\mathrm{Ca}$ in desferal and deferasirox groups were $8.11 \pm 0.32 \mathrm{mg} / \mathrm{dL}$ and $8.04 \pm 0.2 \mathrm{mg} / \mathrm{dL}$ respectively $(P=0.47)$.

\section{Discussion}

The result of our study showed that mean 24 hours urine Ca was not significantly different between groups. Among patients who had hypercalciuria, $60 \%$ were administered desferal and $40 \%$ received deferasirox, however, this difference was not significant. It should be noted that our study was conducted on a small proportion of patients.

Table 1. Comparison of laboratory data between two groups

\begin{tabular}{|c|c|c|c|c|c|}
\hline Gender & Variables & & Desferal group & Deferasirox group & $P$ value \\
\hline \multirow{2}{*}{ Male } & \multirow{2}{*}{ Urine calcium (mg) } & $<100$ & $26.6 \%$ & $25 \%$ & \multirow{2}{*}{0.92} \\
\hline & & $\geq 100$ & $73.3 \%$ & $75 \%$ & \\
\hline \multirow{2}{*}{ Female } & \multirow{2}{*}{ Urine calcium (mg) } & $<100$ & $16.6 \%$ & $54.5 \%$ & \multirow{2}{*}{0.06} \\
\hline & & $\geq 100$ & $83.3 \%$ & $45.4 \%$ & \\
\hline \multirow{2}{*}{ Male } & \multirow{2}{*}{ Urine calcium (mg) } & $<250$ & $86.7 \%$ & $66.7 \%$ & \multirow{2}{*}{0.35} \\
\hline & & $\geq 250$ & $13.3 \%$ & $33.3 \%$ & \\
\hline \multirow{6}{*}{ Female } & \multirow{2}{*}{ Urine calcium (mg) } & $<250$ & $91.7 \%$ & $81.8 \%$ & \multirow{2}{*}{0.59} \\
\hline & & $\geq 250$ & $8.3 \%$ & $18.2 \%$ & \\
\hline & Glycosuria (mg) & & $7.4 \%$ & $13 \%$ & 0.51 \\
\hline & $\mathrm{GFR}\left(\mathrm{mL} / \mathrm{min} / 1.73 \mathrm{~m}^{2}\right)$ & & $120.45 \pm 35.25^{b}$ & $112.80 \pm 31.27^{\mathrm{b}}$ & 0.42 \\
\hline & Proteinuria (mg) & & $110 \pm 91.77^{b}$ & $188.09 \pm 514.38^{b}$ & 0.44 \\
\hline & Serum $\mathrm{Cr}(\mathrm{mg} / \mathrm{dL})$ & & $0.68 \pm 0.12^{b}$ & $0.67 \pm 0.11^{\mathrm{b}}$ & 0.47 \\
\hline
\end{tabular}

${ }^{\mathrm{b}}$ Mean \pm SD. 
Additionally, the proportion of glycosuria, proteinuria and eGFR was not significantly different among groups. Several studies have reported tubular dysfunctions - including proteinuria, hypercalciuria, and hyperphosphaturia - in thalassemia patients with normal GFR (19-21). In our study, the GFR of all patients were in normal range.

Numerous studies have reported concerns on the potential nephrotoxic effects of deferasirox. Tubular dysfunctions and proximal renal tubular dysfunction (Fanconi syndrome) have also been reported among deferasirox users (21).

Pathologic studies on rats have shown that deferasirox could cause vacuolization of proximal tubular epithelial cells and has direct toxic effect on cortical tubular cells. Acute tubular necrosis and tubular dysfunction was reported (22).

Cianciulli et al studied 19 patients with thalassemia who had administered deferoxamine. They found excreting large amounts of beta-2-microglobulin which was positively correlated with duration and dosage of therapy (23).

A phase III clinical trial comparing deferoxamine and deferasirox showed a rise in serum $\mathrm{Cr}$ in $38 \%$ of patients receiving deferasirox (mostly at doses of 20 and $30 \mathrm{mg} /$ $\mathrm{kg}$ and in patients who had the most dramatic decrease in liver iron concentration and serum ferritin level). However, $14 \%$ of patients who received deferasirox had a similar increase in serum Cr. Importantly, this rises were occasionally transient and mostly within the normal range $(24,25)$.

\section{Conclusion}

The proportion of hypercalciuria and glycosuria, proteinuria and eGFR were not significantly different in $\beta$-Thalassemia major patients with receiving desferal or deferasirox as a chelating agent.

\section{Limitations of the study}

The low proportion of patients is a limitation of our study. We hope that such studies will be repeated with larger sample size to confirm the renal safety of oral iron chelating agents for widespread use.

\section{Authors' contribution}

FS; participated in study design and research plan, organized the study and prepared the final manuscript. $\mathrm{MD}$ and $\mathrm{AA}$, contributed to acquisition of data, data interpretation and writing the manuscript. All authors read and signed the final paper.

\section{Conflicts of interest}

The authors declare no conflict of interest.

\section{Ethical considerations}

Ethical issues (including plagiarism, data fabrication, double publication) have been completely observed by the authors.

\section{Funding/Support}

This paper is extracted from internal medicine residency thesis of Maryam Darnahal (\# 93-02-30-24649).

\section{References}

1. Graziano JH, Grady RW, Cerami A. The identification of 2, 3-dihydroxybenzoic acid as a potentially useful ironchelating drug. J Pharmacol Exp Ther. 1974;190:570-5.

2. Hershko C. Pathogenesis and management of iron toxicity in thalassemia. Ann N Y Acad Sci. 2010;1202:1-9. doi: 10.1111/j.1749-6632.2010.05544.x.

3. Halliwell B. Protection against tissue damage in vivo by desferrioxamine: what is its mechanism of action? Free Radic Biol Med. 1989;7:645-51.

4. Perera NJ, Lau NS, Mathews S, Waite C, Ho PJ, Caterson ID. Overview of endocrinopathies associated with $\beta$-thalassaemia major. Intern Med J. 2010;40:689-96. doi: 10.1111/j.1445-5994.2010.02254.x.

5. Maggio A, Vitrano A, Capra M, Cuccia L, Gagliardotto F, Filosa A, et al. Improving survival with deferiprone treatment in patients with thalassemia major: a prospective multicenter randomised clinical trial under the auspices of the Italian Society for Thalassemia and Hemoglobinopathies. Blood Cells Mol Dis. 2009;42:247-51. doi: $\quad$ 10.1016/j.bcmd.2009.01.002.

6. Anderson LJ, Wonke B, Prescott E, Holden S, Walker JM, Pennell DJ. Comparison of effects of oral deferiprone and subcutaneous desferrioxamine on myocardial iron concentrations and ventricular function in betathalassaemia. Lancet. 2002;360:516-20.

7. Pennell DJ, Berdoukas V, Karagiorga M, Ladis V, Piga A, Aessopos A, et al. Randomized controlled trial of deferiprone or deferoxamine in beta-thalassemia major patients with asymptomatic myocardial siderosis. Blood. 2006;107:3738-44. doi:10.1182/blood-2005-07-2948

8. Modell B, Khan M, Darlison M. Survival in betathalassaemia major in the UK: data from the UK Thalassaemia Register. Lancet. 2000;355:2051-2. doi: 10.1016/S0140-6736(00)02357-6

9. Giardina PJ, Grady RW. Chelation therapy in betathalassemia: the benefits and limitations of desferrioxamine. Semin Hematol. 1995;32:304-12.

10. Borgna-Pignatti C, Rugolotto S, De Stefano P, Zhao H, Cappellini MD, Del Vecchio GC, et al. Survival and complications in patients with thalassemia major treated with transfusion and deferoxamine. Haematologica. 2004;89:1187-93.

11. Porter JB. Practical management of iron overload. Br J Haematol. 2001115:239-52.

12. Lauderdale DS, Thisted RA, Wen M, Favus MJ. Bone mineral density and fracture among prevalent kidney stone cases in the Third National Health and Nutrition Examination Survey. J Bone Miner Res. 2001;16:1893-8. doi: $\quad 10.1359 / j b m r .2001 .16 .10 .1893$

13. Melton LJ, Crowson CS, Khosla S, Wilson DM, O'Fallon WM. Fracture risk among patients with urolithiasis: a population-based cohort study. Kidney Int. 1998;53:459-64. doi: 10.1046/j.1523-1755.1998.00779.x

14. Quinn CT, Johnson VL, Kim H-Y, Trachtenberg F, Vogiatzi MG, Kwiatkowski JL, et al. Renal dysfunction in patients with thalassaemia. Br J Haematol. 2011;153:111-7. doi: 10.1111/j.1365-2141.2010.08477.x. 
15. Galanello R, Origa R. Beta-thalassemia. Orphanet J Rare Dis. 2010;5:11. doi: 10.1186/1750-1172-5-11.

16. Taylor EN, Curhan GC. Demographic, dietary, and urinary factors and 24-h urinary calcium excretion. Clin J Am Soc Nephrol. 2009;4:1980-7. doi: 10.2215/CJN.02620409.

17. Curhan GC, Taylor EN. 24-h uric acid excretion and the risk of kidney stones. Kidney Int. 2008;73:489-96. doi:10.1038/ sj.ki.5002708

18. Díaz-García JD, Gallegos-Villalobos A, Gonzalez-Espinoza L, Sanchez-Niño MD, Villarrubia J, Ortiz A. Deferasirox nephrotoxicity-the knowns and unknowns. Nat Rev Nephrol. 2014 ;10:574-86. doi: 10.1038/nrneph.2014.121.

19. Smolkin V, Halevy R, Levin C, Mines M, Sakran W, Ilia $\mathrm{K}$, et al. Renal function in children with beta-thalassemia major and thalassemia intermedia. Pediatr Nephrol. 2008 ;23:1847-51. doi: 10.1007/s00467-008-0897-8.

20. Aldudak B, Karabay Bayazit A, Noyan A, Ozel A, Anarat A, Sasmaz I, et al. Renal function in pediatric patients with beta-thalassemia major. Pediatr Nephrol. 2000;15:10912 .
21. Sumboonnanonda A, Malasit P, Tanphaichitr VS, Ongajyooth S, Sunthornchart S, Pattanakitsakul S, et al. Renal tubular function in $\beta$-thalassemia. Pediatr Nephrol. 1998; 12:280-3.

22. Koliakos G, Papachristou F, Koussi A, Perifanis V, Tsatra I, Souliou E, et al. Urine biochemical markers of early renal dysfunction are associated with iron overload in betathalassaemia. Clin Lab Haematol. 2003;25:105-9.

23. Rafat C, Fakhouri F, Ribeil J-A, Delarue R, Le Quintrec M. Fanconi syndrome due to deferasirox. Am J Kidney Dis. 2009;54:931-4. doi: 10.1053/j.ajkd.2009.03.013.

24. Sánchez-González PD, López-Hernandez FJ, Morales AI, Macías-Nuñez JF, López-Novoa JM. Effects of deferasirox on renal function and renal epithelial cell death. Toxicol Lett. 2011;203:154-61. doi: 10.1016/j.toxlet.2011.03.018.

25. Cianciulli P, Sollecito D, Sorrentino F, Forte L, Gilardi E, Massa A, et al. Early detection of nephrotoxic effects in thalassemic patients receiving desferrioxamine therapy. Kidney Int. 1994;46:467-70.

Copyright $\odot 2018$ The Author(s); Published by Nickan Research Institute. This is an open-access article distributed under the terms of the Creative Commons Attribution License (http://creativecommons.org/licenses/by/4.0), which permits unrestricted use, distribution, and reproduction in any medium, provided the original work is properly cited. 